\title{
Comprehensive Planning for Growth Management in Florida ${ }^{1}$
}

Roy R. Carriker ${ }^{2}$

For more than two decades, city and county officials throughout Florida have been busy complying with state legislation that requires them to develop and adopt local government comprehensive plans. For many counties in Florida, the greatest challenges to government are posed by the intense pressures of sustained rapid growth in population as well as in economic activity. Florida's system of state, regional, and local comprehensive planning was designed and implemented with the hope that it would help the state manage growth. Florida's planning law intends that Florida residents have ready access to the process of developing, amending, and implementing comprehensive plans. This publication is intended to serve as a primer to the subject of comprehensive planning in Florida, with the hope that it will be useful to residents who wish to play a greater role in community affairs.

\section{Local Government Comprehensive Planning: The Early Years}

The Florida legislature enacted the first of several land use planning programs during the early 1970s. Among these were the Environmental Land and Water Management Act of 1972, which created two programs: the Areas of Critical State Concern (ACSC) program, and the Developments of Regional Impact (DRI) program. The former provides for state designation of "Areas of Critical State Concern" which, because of their important environmental significance, are accorded greater state oversight of planning and land development regulation. The latter program provides for heightened regulation in the planning and approval of very large developments that affect more than one county.

Also in 1972, the Florida legislature passed the Florida State Comprehensive Planning Act. This act ordered the Division of State Planning of the Florida Department of Administration to prepare a state comprehensive plan designed to "provide long-range guidance for the orderly social, economic, and physical growth of the state, setting forth goals, objectives, and policies (1972 Florida Laws, Chapter 72-295)."

To assist in implementation of the Environmental Land and Water Management Act, the 1972 Florida legislature created the first Environmental Land Management Study (ELMS) Committee. This committee sponsored many

1. This is EDIS document FE642, a publication of the Food and Resource Economics Department, Florida Cooperative Extension Service, Institute of Food and Agricultural Sciences, University of Florida, Gainesville, FL. Published July 2006. Please visit the EDIS website at http://edis.ifas.ufl.edu.

2. Roy R. Carriker, Professor, Food and Resource Economics Department, Florida Cooperative Extension Service, Institute of Food and Agricultural Sciences, University of Florida, Gainesville, FL.

The Institute of Food and Agricultural Sciences (IFAS) is an Equal Opportunity Institution authorized to provide research, educational information and other services only to individuals and institutions that function with non-discrimination with respect to race, creed, color, religion, age, disability, sex, sexual orientation, marital status, national origin, political opinions or affiliations. U.S. Department of Agriculture, Cooperative Extension Service, University of Florida, IFAS, Florida A. \& M. University Cooperative Extension Program, and Boards of County Commissioners Cooperating. Larry Arrington, Dean 
progressive proposals intended to foster the sensible development of the state. Among its achievements was the Local Government Comprehensive Planning Act of 1975. This legislation recognized the traditional role of local government in land use control and was intended to stimulate and guide the development and implementation of comprehensive plans by local government. It contained two essential mandates: (1) local governments were to adopt comprehensive plans, and (2) development must conform to the plans. The act specified a number of elements to be included, such as for sewer, solid waste, drainage, and potable water facilities that were to be correlated with the land use element. The local government comprehensive plans were to be adopted by July 1, 1979 .

Meanwhile, the Division of State Planning worked diligently to comply with the 1972 planning law, and the resulting state comprehensive plan was approved by the outgoing administration and duly submitted for review and approval by the 1980 legislature. However, the legislature refused to approve the Plan and specifically directed that no part of it be implemented. Thus, eight years after the 1972 legislation calling for a State Comprehensive Plan, the state planning process had come to naught.

One reason for the apparent failure of the planning process was that there was never a clear conception of how the plan was to be implemented (what actions of state government the plan would guide and by what means the plan would be used to control those actions). Second, the plan was not drafted by those in a position to implement it. The Division of State Planning was an independent planning group that was administratively separate from the agencies that make program decisions, and the latter were reluctant to embrace the plan. Moreover, by the end of the decade of the 1970s, the enthusiasm of the legislature for planning and environmental protection had declined, at least temporarily.

Certain deficiencies also hampered the effectiveness of the Local Government Comprehensive Planning Act of 1975. First, there was no provision for controlling the substance of the plans. It was possible for a local government to go through the required procedures of planning without ever altering the existing pattern of development. Second, there was no method to ensure consistency of plans among planning entities. In many cases, the plans were incompatible.

\section{Learning from Experience: Reformation of Comprehensive Planning}

In 1982, Governor Bob Graham issued an executive order which created the second Environmental Land Management Study Committee. The major conclusion of the ELMS II was that Florida needed a system of integrated state, regional, and local planning for growth management. Responding to the recommendations of the ELMS II Committee, the 1984 legislature passed the State and Regional Planning Act (codified at Chapter 186, Florida Statutes). It called for the development of a State Comprehensive Plan and directed the Executive Office of the Governor to prepare a draft plan within six months. The version adopted by the legislature in 1985 established goals for ten- and fifteen-year planning periods on twenty-five subject areas.

The 1984 State and Regional Planning Act also required that each state agency prepare an "agency functional plan" within six months to one year from legislative adoption of the State Comprehensive Plan. These agency functional plans were to demonstrate the manner in which agency programs and budget allocations would pursue the goals established in the State Comprehensive Plan. By having plans developed by the same agencies that would implement them, the 1984 comprehensive planning legislation attempted to avoid the major shortcoming of the previous comprehensive planning efforts.

The 1984 State and Regional Planning Act also required that "Comprehensive Regional Policy Plans" be completed within eighteen months from the date of adoption of the State Plan, and submitted for approval by the legislature. This meant that the eleven regional planning councils in the state were required to have their plans available by November 30, 1986. 
The legislature followed its state and regional planning law by passing the Local Government Comprehensive Planning and Land Development Act of 1985 (codified at Chapter 163, Florida Statutes) that substantially amended the 1975 Local Government Comprehensive Planning Act. It required local governments to amend their existing plans to ensure consistency with the State and Regional plans. Failure to do so would result in loss of state revenue-sharing to local governments, and loss of grant money controlled by the state government.

The 1985 Act requires that local government comprehensive plans be certified by the Florida Department of Community Affairs as being in compliance with statutory requirements. The Department of Community Affairs adopted detailed rules setting up minimum criteria for approval of local plans. Chapter 9 J-5, Florida Administrative Code is entitled "Minimum Criteria for Review of Local Government Comprehensive Plans and Determination of Compliance." The Act also requires local governments to enact the necessary implementing ordinances within one year of submitting their plans to the Department of Community Affairs. These provisions sought to plug loopholes that had thwarted implementation of previous comprehensive plans.

\section{The Local Government Comprehensive Planning Process}

The structure of Florida's comprehensive planning process is tiered. The top tier of planning is embodied in the state comprehensive plan, which contains broad goals and policies dealing with subjects ranging from education to the environment. The "Chief Planning Officer" of the state is the Governor. The planning statute specifically states that there shall be no "Future Land Use Map" for the state. The state comprehensive plan was adopted as law by the legislature and can be found in Florida Statutes, Chapter 186.

Below the state-level tier of the planning structure are the eleven regional planning councils that are required to adopt Strategic Regional Policy Plans consistent with the state plan to address regional issues. Below the regional tier of the planning structure are the approximately 470 local government comprehensive plans, which are to be consistent with both the regional and state plans. The statute requires that citizens be given the opportunity to participate in the planning process to the fullest extent possible.

To help assure that local plans will be meaningful and substantive, the Growth Management Act sets forth a number of mandatory elements that must be included in each plan. Examples of these elements include Conservation, Land Use, Transportation, Capital Improvements, Intergovernmental Coordination, Housing, Public Facilities, Coastal Zone Management, and Recreation and Open Space. Local plans are required to build upon appropriate and specific data and analysis to help assure that the plans have a sound basis. For example, the plans are to be based upon an analysis of existing land uses and resources. Future land uses are to be designated with reference to the estimated needs of the projected population of the community. The statute intends that the plan be able to direct growth in a manner that protects environmental resources, conserves tax dollars, promotes efficient use of public infrastructure and services, and implements the community's vision of itself.

An important component of the Department of Community Affairs' Minimum Criteria rule is a requirement that local governments adopt policies that discourage urban sprawl. This requirement has led local governments to adopt various measures to contain sprawl development, such as urban services boundaries. The Department of Community Affairs reviews and comments on every local comprehensive plan, and must approve the plans and any amendments to the plans before they are legally effective. No development may be approved by local governments until their plans or plan amendments have been reviewed and approved by the state agency.

Recognizing that comprehensive plans must be updated to account for growth trends and to rectify inadequacies exposed by experience, the state planning statute requires that each local government adopt an Evaluation and Appraisal Report (EAR) every seven years. The EARs are submitted to the state agency for review. 
The legislature intended that the local comprehensive plans be instrumental in local government decisions regarding land development patterns and the allocation of local government resources. The plans must be implemented through the adoption of appropriate land development regulations. They must provide guidance for budget decisions, and must be adhered to when the local governments consider applications for land development. To assure that these purposes are attained, the state planning legislation makes each local government comprehensive plan a legally binding document. Every ordinance and land use decision the local government makes must be consistent with the plan. Otherwise they are invalid.

While the Department of Community Affairs provides oversight to ensure that local government comprehensive plans meet minimum criteria, the planning legislation did not provide for state agency oversight to ensure that the local governments actually follow the law and implement the plans with the adoption of appropriate land development regulations. However, the Act did include a broad grant of standing to citizens to challenge the adoption and amendment of the plans and land development regulations through administrative procedures. Citizens may also bring action in circuit court to challenge a local government decision that is inconsistent with the comprehensive plan.

To provide some degree of stability and predictability in the implementation of local plans, the state only allows the adoption of large-scale plan amendments twice a year. The intent was to prevent plan amendments from becoming a routine process of changing the plan to accommodate successive development proposals.

Florida's planning act requires local governments to establish and implement a "concurrency management" system. This is a financial planning tool that requires local governments to have in place certain public services and infrastructure, such as roads, sewer, water, solid waste collection, drainage, parks and recreation, mass transit, and perhaps schools, at an acceptable level of service concurrent with the impacts of new development. If these services are unavailable, the development is not to be approved. In complying with the concurrency provisions, local governments must first project the need for public services and facilities to serve the projected population at a designated level of service over the planning horizon, which may be as much as twenty or thirty years. The budget process is to be tied to a five-year capital improvements element for the services needed in order to maintain concurrency with the impacts of development.

It is noteworthy that the concurrency management system does not require developers to supply services and infrastructure. Rather the system holds the local government responsible for planning for and providing the infrastructure and services needed to serve new development. Many local governments impose impact fees or require exactions and dedications to offset the cost of providing new services. But the concurrency provision is not in the first instance a growth control program.

\section{Issues in Implementing Comprehensive Plans}

Published commentaries on Florida's system for comprehensive planning have included a number of issues that are summarized briefly in this section.

\section{Neighboring jurisdictions sometimes fail to} coordinate their plans and land development ordinances. Some writers point to evidence that the planning system has failed to ensure that plans be compatible between and among adjacent cities and across county borders. They cite instances where land use patterns change abruptly at the boundary between some cities or counties. Failure to coordinate plans across adjacent communities can result in incompatible uses cropping up in close proximity to each other. Suggestions for addressing this problem call for the legislature to empower the regional planning councils to take a more active role in coordinating the planning decisions of neighboring communities.

Plans adopted for slow-growth counties prove inadequate when the pace of growth speeds up. In reviewing the first round of county comprehensive plans in the early 1990s, the state did not always require small, rural communities to achieve the same 
degree of precision as it did the more urban communities. While this seemed reasonable at the time, some of these same local governments a decade later are experiencing significant growth pressures. They find that they are now hampered by plans adopted earlier, which contain insufficient detail to cope adequately with the demands made upon the community by new growth. The implicit advice for slow-growth communities is to plan adequately for the possibility that they might experience unanticipated growth in the future.

Thousands of pre-platted home sites were "grandfathered" by the planning laws. Lots that had been platted and sold before the growth management legislation was enacted were exempted from the minimum criteria rules that apply to all subsequent development. These properties were said to be vested from new regulation. "Vested" is a legal term which means government may not apply new laws to developments that existed before enactment of the new laws. As a consequence, the state's planning requirements did not apply to large segments of the state, many of which were in rural areas beyond urban service boundaries. Today's planning laws would require increased densities, addition of public amenities, avoidance of natural areas, and other standards that will not be met on the exempted properties. A possible solution to the problem would provide incentives to the owners to apply the new rules to the largely vacant platted areas and to involve absentee owners in a program to recombine parcels and redevelop the platted communities to achieve more desirable development patterns, and, presumably, enhanced property values.

The planning laws do not require amendment of local comprehensive plans to reflect current data and analysis. Although the state requires each local government to adopt an Evaluation and Appraisal Report (EAR) and submit it for review, the state does not require the plans be amended to reflect changes in infrastructure needs and service requirements. Since the EAR is not a plan amendment, it does not have to satisfy the minimum criteria rule. Critics argue that this represents a lost opportunity for the local comprehensive planning process to evolve and make the plans better.
State law does not provide state oversight to ensure that local governments follow the law and implement the plan. The Department of Community Affairs does not review land development regulations unless the process is initiated by a citizen. Neither does the agency oversee the issuance of development permits to ensure compliance with the local plan. This places the burden of enforcement on the citizens of Florida. Challenging a local government's failure to adhere to the comprehensive plan can involve time and expense beyond the means of most citizens.

Incentives for plan compliance are often lacking. Incentives might be more effective and less costly than the threat of litigation to ensure plan compliance. Streamlining development approval by coordinating the permitting criteria and process of multiple regulatory agencies around consistency with the comprehensive plan would make plan compliance much easier. Coordinating the transportation decisions at all levels with reference to the approved local plans would help facilitate plan compliance.

New franchise areas for private utilities are sometimes approved without regard to the local government plan or the impact on land use patterns. In Florida, private utilities are regulated by the Public Service Commission (PSC). That approval process is not required to consider the provisions of local comprehensive plans, with the result that private utilities have been allowed to serve areas beyond the urban services boundary established by the local governments as a way to implement their approved comprehensive plans.

\section{Growth Management and the 2005 Florida Legislature}

Legislation in 2005 created significant changes in Florida's growth management laws. It made school concurrency mandatory and tightened some financial feasibility standards for transportation facilities. It also required local governments to adopt "proportionate fair share mitigation" ordinances through which a developer may choose to satisfy all school and transportation concurrency requirements. Under this provision, development permits cannot be denied if the developer pays its "fair-share contribution" of the cost to mitigate development 
impacts (some refer to this as a "pay-and-go"

provision). The 2005 legislation included incentives

for local governments to adopt urban service

boundaries, making future land use map amendments

within an urban service boundary exempt from State

review. The Act included the first major funding for

infrastructure in many years, a total of $\$ 1.5$ billion

composed of $\$ 750$ million in recurring and $\$ 750$

million in non-recurring revenues. 